\title{
Ergativity Case-Marking in Batak Toba Language
}

\author{
Sisila Fitriany Damanik ${ }^{1}$, Mulyadi ${ }^{2}$ \\ ${ }^{1}$ Universitas Negeri Medan, Indonesia \\ ${ }^{2}$ Universitas Sumatera Utara, Indonesia \\ SFDamanik@gmail.com
}

\begin{abstract}
Batak Toba Language (BTL) is an accusative, ergative and split-S language. It is called accusative because BTL has an active diathesis basic construction. In the BTL, the active diathesis clause is morphologically marked on the verb (head marking) by adding the prefix /ma-/, /maN-/ or zero prefix (occurred in some verbs that can stand without affixes). BTL is categorized ergative, firstly, because in the basic $S$ argument from the intransitive verbs in BTL can be semantically gets the most influence from the verb, and it is also applied as $O$ of intransitive verbs. Secondly, By using treatment parameters $S$ equal to $O$ and different from $A$ in nominal construction. BTL is also categorized as split-S language because the behavior is that the agent-like argument of intransitive verb $(\mathrm{Sa}$ ) in transitive verbs can be nominalized with Ipar-I affixes, while the patient-like arguments of other intransitive patients cannot be nominalized with /par-/ affixes.
\end{abstract}

Keywords

accusative; ergative;

split-S; agent-like

argument; patient-like

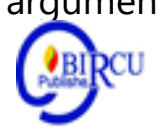

\section{Introduction}

Batak Toba Language (BTL) is the mother tongue used by speakers originally in the North Tapanuli area, one of areas located in North Sumatra province, in Indonesia. The BTL functions as a tool of communication between families, customs, language, culture, and as a language introduction to elementary schools (besides Bahasa Indonesia). Considering the importance of its function as regional language, BTL needs to be fostered and developed. BTL is a species of Protomalay language, so in learning it, people can be helped by making Bahasa Indonesia as a term of reference. For example, the prefix / $\mathrm{maN}-/$ in BTL can be considered as the prefix /meN-/ in Bahasa Indonesia.

In this article the author tries to uncover the problem of the ergativity in BTL. If the typology of ergativity is evident in languages that have argument markers, both with clitics or cases or cross references, such as English, Latin, Dyirbal, and others, BTL is a language that does not have these tools for identifying arguments alliance. However, not all languages that have morphological marking can be linearly drawn in the alliance of arguments to form the type of language in accordance with the requirements of typology theory. Tagalog is a case of language which has a morphological marker that has been discussed typologically for years but is not linear with the theory of typology of ergativity. The Tagalog language was once claimed to be an accusative language, an ergative language, and not an accusative or ergative language (see Artawa, 1998: 115). Cases like Tagalog also occur in western Autronesian languages including the BTL. In this case, the writer feels challenged to explore the BTL with typology theory. That is because the BTL does not recognize markers, whether in the form of cases (such as Latin), or clitics markers such as languages in eastern Indonesia. The affixes of the BTL are not always parallel to the marking, especially when related to the semantic role of their arguments in relation to the typology of ergativity. Therefore, the writer tries to find a gap to be able to ideologize the BTL in the concept of ergativity. 


\section{Review of Literature}

There is a lot of research on typology of language (ergative-accusative) that have been done by experts. In this article, the theory used is Dixon's (1994) ergative-accusative typology theory. In the typology model, the types of language are known as accusative language types, ergative language types, and split-S language types (see Dixon, 1994: Artawa, 1997; Hanafi, 1999; Arka, 2000; Sawardi, 2002).

The concept of typology started with sentence analysis based on predicators and arguments (Djunaidi, 2000). All languages in the world distinguish verbs with one core (intransitive), and verbs with more than one core (transitive \& transitive). This is also the case with the core ideas of the Unaccusative Hypothesis (Perlmutter: 1978) which stated that in all languages there are two classes of intransitive verbs - unaccusative and unergative which differ in terms of grammatical relations certified by their single argument. In some languages, almost every verb can be categorized firmly into transitive or intransitive verbs, for example Latin, Dyrbal and Japanese (Kishimoto: 1996); in other languages, the distinction between transitive and intransitive becomes more fluid, for example English. There are also languages where all intransitive verbs can be formed into transitive verbs, for example Fijian (Dixon, 1996: 6).

These arguments form basic grammatical relations. The only core argument in intransitive verbs will be mapped to $S$ (in general it is indeed a grammatical subject and Dixon himself calls it a Subject, but the substance is a single argument). If the verb has two arguments, then one of the arguments will be mapped to A (agent) and the other will be mapped to $\mathrm{O}$ (object) based on its semantic role. A includes roles such as the agent in affect verbs, donors in giving verbs, speakers in speaking verbs and the role of perceivers in attention verbs. In certain languages the behavior of basic grammatical relations is morphologically marked, but in other languages it is not. The marking strategy can occur in the verb (head marking), in the argument (dependent marking), or in both, in the verb and in the argument.

\section{Discussion}

\subsection{BTL as an Accusative Language}

Languages that treat the $\mathrm{S}$ equally to $\mathrm{A}$ are called accusative languages, and languages that treat the $\mathrm{S}$ equally to $\mathrm{O}$ are called ergative languages. Languages whose $\mathrm{S}$ is similar to $\mathrm{A}$ are treated equally to $\mathrm{A}$ and those whose $\mathrm{S}$ is similar to $\mathrm{O}$ are treated equally to as $\mathrm{O}$ are called split languages (Dixon, 1994, Arka, 2000). One of these forms of treatment is indicated overtly by morphological marking. In accusative languages, like English, $\mathrm{S}$ is treated equally to $\mathrm{A}$ in transitive verbs. Languages that treat $\mathrm{S}$ equally to A are called languages that use the nominative-accusative alliance system, or accusative language. For example, the English intransitive sentence, She walked and the transitive sentence She called her. S (the only argument in the intransitive verb) in that sentence is morphologically defined in the equal morphological form as the argument $\mathrm{A}$ in transitive verbs. Both of them take morphologic form of she which is distinguished from the argument $\mathrm{O}$ which takes the morphologic form of her. She is a nominative case, which is a case used to mark A in transitive verbs such as She called her (distinguished from her used to mark $\mathrm{O}$ in transitive verbs). The equal treatment between $\mathrm{S}$ and $\mathrm{A}$ is generally described as follows: 
Treatment

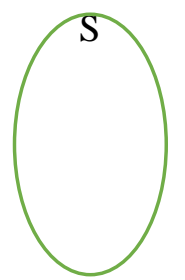

A
English language

(a) She (*her) walked

(b) She called her

\section{Figure 1: The equal treatment for $\mathrm{S}$ and $\mathrm{A}$}

According to Basaria (2006) BTL is an accusative language because it has an active diathesis basic construction. In the BTL, the active diathesis clause is morphologically marked on the verb (head marking) by adding the prefix $m a$ - or zero prefix (occured in some verbs that can stand without affixes). Based on morphosyntactic studies, verbs that can occur in the construction of transitive clauses are affixed with active markers, namely the prefix / $\mathrm{maN}-/$, as in the following example:

(1) Amang man-gadis boras di onan

Father ACT-sells rice at market

'The father sells rice at the market.'

(2) Ibana ma-nutung harotas

$\mathrm{He} / \mathrm{She}$ ACT- burned paper

'He/She burned the paper.'

In examples (1) and (2), amang 'father' and ibana 'she/he' are A in the transitive verbs with ACT (active) marker man-gadis and man-nutung. But in the intransitive clause the Subject can have the equal treatment as A. It can be seen in the following example;

(3) Ibana mar-tangiang

She/he MED-praying

'She/He is praying.'

Ibana 'she/he' in example (3) is $\mathrm{S}$ with a verb that has a medial diathesis (MED) marker in reflexive construction. Thus, it can be seen that the equal treatment pattern occurs between $S$ in example (3) with A in examples (1) and (2).

\subsection{BTL as An Ergative Language}

The second type of language is ergative language. Ergative language treatment models differ from Figure (1). The model in figure (2) below is known as the ergative-absolutive alliance system, or it is called ergative, that is, the language that the treatment in $\mathrm{S}$ is equal to $\mathrm{O}$. This kind of treatment system is shown in Dyirbal language. Ergative language behavior is described as follows:

\section{Treatment}

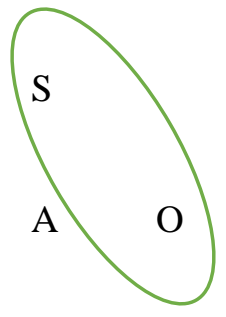

\section{Dyirbal language}

(a) пuma

Father-ABS

'Father is back'

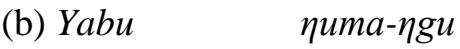

Mother-ABS father-ERG saw

'Father saw mother'

Figure 2. The equal treatment for $\mathrm{S}$ and $\mathrm{O}$ 
In this example, it appears that the intransitive verb's S numa 'father' in example (a) is treated equally to the transitive verb's $\mathrm{O}$ in example (b), both of which are marked with ABS (absolute) which is morphologically unmarked. While A (agent) in the transitive verb (b) is marked ERG (ergative) $\eta g u$ to distinguish from $\mathrm{S}$ and $\mathrm{O}$.

BTL is also an ergative language. As it was stated by Comrie (1989) and Artawa (2004) that ergative-type sentences can be seen from a morphological and syntactic point of view.

(4) Si Ucok tarsonggot

Name(Ucok) surprised

'Ucok is surprised' 'his-'.

In example (4), the sentence is an ergative type where the S ' $U c o k$ ' is treated equally to $\mathrm{P}-n a$

Ucok serves the basic $\mathrm{S}$ argument from the intransitive verbs tarsonggot 'surprised' but semantically Ucok is the $\mathrm{S}$ that gets the most influence from the verb, therefore it also applies as $\mathrm{O}$ of intransitive verbs tarsonggot 'surprised'. The subject of clause (4) is treated accusatively as a sufferer by the verb.

By using treatment parameters $\mathrm{S}$ equal to $\mathrm{O}$ and different from $\mathrm{A}$, ergativity can also be found in nominal construction. The following example explains the ergativity in BTL nominal construction. Parmunuon Munir 'Munir murdur', the nominal phrase construction starts from mamunu Munir 'killing Munir' with the nominal construction $m a-\mathrm{V}+\mathrm{N}$, and $\mathrm{N}$ here is the $\mathrm{O}$ of transitive verbs. While in paraloan Munir 'Munir's opposition', the nominal phrase starts from maraloan Munir 'Munir opposed' in which Munir is function as S of transitive verb. The $\mathrm{S}$ treatment is equal to $\mathrm{O}$ in the par-+ V-an construction, furthermore BTL can be marked as the ergative pattern.

\subsection{Is BTL a Split-S Language?}

The third type of language is a Split-S language. There are two markings on split intransitive verbs, they are $\mathrm{S}$ that are similar to an $\mathrm{A}$ ( called as $\mathrm{Sa}$ ), which is marked differently from an $\mathrm{S}$ that is similar to an $\mathrm{O}$ (called as So). The split can be described as the following example from Javanese language;

Treatment

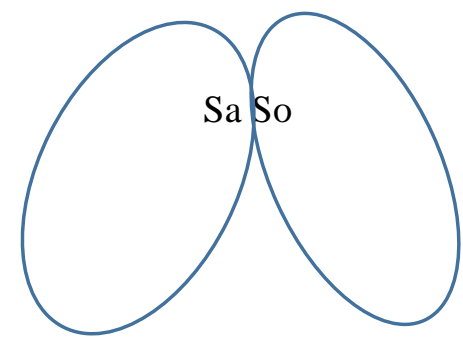

A
$\mathrm{O}$

\section{Javanese language}

(a) Tini

Name fall

'Tini fell'

(b) Tini

njoget

Name $\quad$ ACT-dance

'Tini danced'

Figure 3. The equal treatment for $\mathrm{S}$ and $\mathrm{A}$

In the sentence (a) example, the $\mathrm{S}$ 'Tini' behaves like a patient so that the verb is not given a nasal as an active (ACT) marker. The sentence subject (b) has a behavior like an A (can control the patient), then the verb is given an active marker nasal ACT. 
Dixon (1994) as the originator of this typology model did not explicitly mention the concept of being treated equally between $\mathrm{A}$ and $\mathrm{S}, \mathrm{O}$ and $\mathrm{S}$, and how $\mathrm{S}$ is treated equal as $\mathrm{A}$ or $\mathrm{S}$ is treated equal as O. This is in line with what Arka (2000) stated that the forms of treatment between one language and another are different. As a parameter, determining the form of this treatment must be sought in the relevant language.

In this case, the split-S parameters applied to one particular language may not be suitable for other languages. Although grammatically Indonesian and Javanese can be considered to be similar, the split-S parameters of Javanese (see Sawardi, 2002) cannot be applied to Indonesian, as well as to BTL. In BTL, the S which is similar to A (called as Sa) are also seen in the following intransitive sentences, as can be seen in the following example;

$$
\begin{aligned}
& \text { (5) o hundul hami } \\
& \text { MED-sit we } \\
& \text { 'We are sitting.' } \\
& \text { (6) o modom ibana } \\
& \text { MED-sleep she/he }
\end{aligned}
$$

'She/He is sleeping.'

From examples (5) and (6) above, the subjects hami 'we' and ibana 'she/he' behave like patients because they are positioned at the end of the clause, but the construction of clauses with verbs without affixes is an original intransitive clause which is medially diathetic because the place where the action falls stated by the predicate is the subject itself namely hami and ibana.

\subsection{Distinguishing A and O in BTL}

The following section shows how the BTL distinguishes A and O, and how $\mathrm{S}$ that resembles $\mathrm{A}$ is distinguished from $\mathrm{S}$ that is similar to $\mathrm{O}$. The determination of this parameter is motivated by the thought that each language distinguishes the agent's argument and the patient's argument. There will be chaos if the two types of arguments are not clearly distinguished. For example, if there is a sentence Tarida manggotil Ucok 'Tarida pinched Ucok', linguistically, it is not distinguished which arguments did manggotil 'pinch' action and which arguments are subjected to the act of manggotil. It is surely made language users confused. Each language is ensured to have its own way of distinguishing the two types of arguments. In Bahasa Indonesia, for example, sorting order is one way to arrange both types of arguments. The arguments mentioned before the predicate are A and the arguments mentioned after the predicate are considered as P. Unlike the case of BTL, agents are not always mentioned before the predicate and not always the patient is the argument that is mentioned after the predicate, as can be seen in the following example;

(7) Manuhor manuk inang di onan,

Buy chicken mother at market

'Mother is buying chicken at the market.'

From the example (7) both arguments manuk 'chicken' and inang 'mother' are positioned after the predicate manuhor 'buy'. The position of the predicate can be altered without changing the meaning, as follows;

(8) Inang manuhor manuk di onan

Mother buy chicken at market

'Mother is buying chicken at the market.'

In the transitive clause, the following affixes can be attached to the verb so that the Agent's argument takes action on the Patient's argument;
(9) $\mathrm{maN}-\mathrm{i}$
$\rightarrow$ manaruh
'drop off'
maN-hon $\rightarrow$ manaruhon
'deliver'
(11)

$$
\text { maN-i } \rightarrow \text { manggoliti }
$$
'pinch' 
(12)

(16)

\author{
'bring each other's (thing)' \\ 'put each other'(thing) down' \\ 'sell each other's (thing)' \\ 'pay attention to' \\ 'elevate'
} sentences;

It is different with the intransitive verbs' case. Take a look at the following intransitive

(17) maringkat ibana

run he/she

(18) madabu ibana

Fall he/she

She/He fell off

Example (9) is an intransitive sentence with an agent-like argument in transitive sentence (Sa, in Dixon's term) in which the argument, ibana 'she/he' can control its activity. Conversely, in example (10), the argument ibana 'she/he' resembles patient $\mathrm{O}$ (So, in Dixon terms) in a transitive sentence in which the argument ibana 'she/he' cannot control the activity, and even subject to work. The argument in sentence (9) can be nominalized by adding the affix / par-/ to be parringkat 'runner' while the argument in sentence (10) cannot be nominalized by affix /par-/ to *pardabu.

From the case of the acceptance of parringkat 'runner' nominalization, and the rejection of *pardabu nominalization, it can be concluded that BTL has a Spilt-S behavior. The behavior is that the agent-like argument of intransitive verb $(\mathrm{Sa})$ in transitive verbs can be nominalized with /par-/ affixes, while the patient-like argument of other intransitive cannot be nominalized with /par-/ affixes. Thus, the parameter is used to determine the split-S of BTL intransitive verbs.

In contrast to previous studies, in Javanese and Balinese language, the way to determine the split-S is by determining nasal markers (see: Sawardi, 2002, Arka, 1998, Arka, 2000) especially on the verb, then how to determine the behavior of Split-S of BTL (especially morphological case) in this article, in principle, the agent-like arguments in intransitive verbs are treated differently from arguments that are similar to patients in intransitive verbs. In the research of Sawardi (2002) and Arka (1998), the reference markers are seen as formative forms that can be identified, both morphologically and phonologically. In this article, split-S is determined by the process of nominalizing the argument of intransitive verbs in the form of a process, namely the nominalization of arguments to the morphological form of /par-/ in BTL. Thus, the marking is not a morphological form, but a process of nominalization. The parameters are intransitive verb arguments that can be nominalized by affixes /par-/ are agent-like arguments (Sa) and arguments that cannot be nominalized by affixes /par-/ are patient-like arguments (So).

Next, one of the meanings of /par-/ affixes in BTL is to form nouns whose meanings indicate the owner or signify one's profession. Agent-like intransitive verb arguments can be nominalized with /par-/ affixes. In contrast, patient-like intransitive verb arguments cannot be nominalized with /par-/.

The following words are the examples of agent-like intransitive verb arguments that can be nominalized with /par-/ affixes.

(19) Marende 'sing'

(20) Marhobas 'giving service'

(21) Marbal 'playing football'

(22) Marjamita 'giving sermon'

(23) Maranak 'having child' parende 'singer'

parhobas 'someone who gives service'

parbal 'football player'

parjamita 'preacher'

paranak 'child owner' 
The group of patient-like intransitive verbs arguments that cannot be at all nominalized can be seen as follows;

$\begin{array}{lll}\text { (24) } & \text { Mangangguk } & \text { 'crying' } \\ \text { (25) } & \text { Mardabu } & \text { 'falling' } \\ \text { (26) } & \text { Mulak } & \text { 'going home' } \\ \text { (27) } & \text { Manggoragora } & \text { 'murmuring' } \\ \text { (28) } & \text { Tartumpur } & \text { 'being hit' } \\ \text { (29) } & \text { Rumpak } & \text { 'falling down' } \\ \text { (30) } & \text { Mapultak } & \text { 'exploding' }\end{array}$

The patient-like verbs can never be nominalized with /par-/ affixes. If there is a formation that looks like the nominalization of the intransitive verb argument with /par-/ affix, it can be ascertained that the word formation is not from the relevant intransitive verb.

\section{IV.Conclusion}

Based on the discussion above, it can be concluded that BTL is an accusative, ergative and split-S language. It is called accusative because BTL has an active diathesis basic construction. In the BTL, the active diathesis clause is morphologically marked on the verb (head marking) by adding the prefix /ma-/ or zero prefix (occurred in some verbs that can stand without affixes). Based on morphosyntactic studies, verbs that can occur in the construction of transitive clauses are affixed with active markers, namely the prefix /maN-/. BTL is categorized ergative because in the basic $\mathrm{S}$ argument from the intransitive verbs in BTL can be semantically gets the most influence from the verb, and it is also applied as $\mathrm{O}$ of intransitive verbs. The subject of clause in BTL is treated accusatively as a sufferer by the verb.

By using treatment parameters $\mathrm{S}$ equal to $\mathrm{O}$ and different from $\mathrm{A}$, ergativity can also be found in nominal construction. From the treatment $\mathrm{S}$ is equal to $\mathrm{O}$ in the /par- $/+/ \mathrm{V}$-an $/$ construction, BTL can be marked as the ergative pattern. Ergativity can also be found in nominal construction by using treatment parameters $\mathrm{S}$ is equal to $\mathrm{O}$ and different from $\mathrm{A}$,

BTL is also categorized as split-S language because the behavior is that the agent-like argument of intransitive verb $\mathrm{Sa}$ ) in transitive verbs can be nominalized with /par-/- affixes, while the arguments of other intransitive patients (similar to the arguments of patients in transitive verbs) cannot be nominalized with /par-/ affixes. Thus, the parameter is used to determine the Split-S of BTL intransitive verbs. The parameters are intransitive verb arguments that can be nominalized by affixes /par-/ are agent-like arguments ( $\mathrm{Sa}$ ) and arguments that cannot be nominalized by affixes Ipar-/ are patient-like arguments (So).

\section{References}

Arka, I. W.(1998). From Morphhosyntax to Pragmatic in Balinese: A lexical-Funtional Approach. A Thesis for University of Sydney.

Arka, I. W.(2000). Beberapa Aspek Intransitif Terbelah pada Bahasa-Bahasa Nusantara" dalam Purwo, B. K. (Ed.), Kajian Serba Linguistik. Jakarta: Universitas Katolik Atmajaya.

Arka, I. W. (2000). On Theoretical and Typological Aspects of Termhood in (Eastern) Indonesian Languages. Laporan Penelitian Projek Urge Tahun I, Denpasar.

Basaria, Ida. (2006). Diatesis Bahasa Batak Toba, Suatu Pendekatan Tipologi. http://repository.usu.ac.id/bitstream/handle/123456789/15204/eng-mei20064.pdf? sequence $=1 \&$ is Allowed $=\mathrm{y}$

Artawa, I. K. (1997). Keergativan Sintaksis dalam bahasa: Bahasa Bali, Sasak, dan Indonesia. in Purwo, B.K. (Ed.), PELLBA 10. Yogyakarta: Kanisius.

Artawa, I. K. (1998). Ergativity And Balinese Syntax Part I, II, III. Jakarta: Nusadua

Artawa, I. K. (2004). Balinese Language: A Typological Description. Denpasar: CV Bali Media Adhikarsa. 
Comrie, Bernard. (1989). Language Universals and Linguistic Typology. Great Britain Billing \& Sons Ltd.

Dixon, R.M.W. (1994). Ergativity. Cambridge. Cambridge University Press.

Djunaidi, A.(2000). Tipologi Bahasa Aktif. Artikel Pelbba 14. Jakarta: Pusat Kajian Bahasa dan Budaya Unika Atma Jaya.

Hanafi, N. (1999). Keintransitifan Belah Dua dalam Bahasa Sunda. Artikel Kongres Linguistik IX. Jakarta: MLI.

Kishimoto Hideki. (1996). Split Intransitivity in Japanese and the Unaccussative Hypothesis. Language $72,248-86$.

Moeliono, A. M. (Eds.). (1990). Kamus Besar Bahasa Indonesia. Jakarta: Balai Pustaka.

Sawardi, F. X. (2002). Keterpilahan (Split-S) Morfologi Bahasa Jawa: Suatu Tinjauan Tipologi Morfologi" dalam Linguistik Indonesia Tahun 20, Nomor 1. Jakarta: Masyarakat Linguistik Indonesia. 